\title{
Assembly and Trafficking of Homomeric and Heteromeric Kainate Receptors with Impaired Ligand Binding Sites
}

\author{
Caroline L. Scholefield ${ }^{1} \cdot$ Palmi T. Atlason ${ }^{1} \cdot$ David E. Jane $^{1} \cdot$ Elek Molnár $^{1}$ D
}

Received: 22 June 2018 / Revised: 27 September 2018 / Accepted: 1 October 2018 / Published online: 9 October 2018

(c) The Author(s) 2018

\begin{abstract}
Kainate receptors (KARs) are a subfamily of ionotropic glutamate receptors (iGluRs) mediating excitatory synaptic transmission. Cell surface expressed KARs modulate the excitability of neuronal networks. The transfer of iGluRs from the endoplasmic reticulum (ER) to the cell surface requires occupation of the agonist binding sites. Here we used molecular modelling to produce a range of ligand binding domain (LBD) point mutants of GluK1-3 KAR subunits with and without altered agonist efficacy to further investigate the role of glutamate binding in surface trafficking and activation of homomeric and heteromeric KARs using endoglycosidase digestion, cell surface biotinylation and imaging of changes in intracellular $\mathrm{Ca}^{2+}$ concentration $\left[\mathrm{Ca}^{2+}\right]_{\mathrm{i}}$. Mutations of conserved amino acid residues in the LBD that disrupt agonist binding to GluK1-3 (GluK1-T675V, GluK2-A487L, GluK2-T659V and GluK3-T661V) reduced both the total expression levels and cell surface delivery of all of these mutant subunits compared to the corresponding wild type in transiently transfected human embryonic kidney 293 (HEK293) cells. In contrast, the exchange of non-conserved residues in the LBD that convert antagonist selectivity of GluK1-3 (GluK1-T503A, GluK2-A487T, GluK3-T489A, GluK1-N705S/S706N, GluK2-S689N/N690S, GluK3-N691S) did not alter the biosynthesis and trafficking of subunit proteins. Co-assembly of mutant GluK2 with an impaired LBD and wild type GluK5 subunits enables the cell surface expression of both subunits. However, $\left[\mathrm{Ca}^{2+}\right]_{\mathrm{i}}$ imaging indicates that the occupancy of both GluK2 and GluK5 LBDs is required for the full activation of GluK2/GluK5 heteromeric KAR channels.
\end{abstract}

Keywords Kainate receptors · Glutamate $\cdot$ Ligand binding · Site-directed mutagenesis · Subunit assembly · Trafficking · $\mathrm{Ca}^{2+}$ imaging

\begin{tabular}{|c|c|}
\hline \multicolumn{2}{|c|}{ Abbreviations } \\
\hline AMPA & $\begin{array}{l}(S) \text {-2-Amino-3-hydroxy-5-methyl-4-isoxazole- } \\
\text { propionic acid }\end{array}$ \\
\hline$\left[\mathrm{Ca}^{2+}\right]_{\mathrm{i}}$ & Intracellular $\mathrm{Ca}^{2+}$ concentration \\
\hline ConA & Concanavalin A \\
\hline ECL & Enzyme chemiluminescence \\
\hline EndoF & Peptide- $N$-glycosidase F \\
\hline EndoH & Endoglycosidase $\mathrm{H}$ \\
\hline ER & Endoplasmic reticulum \\
\hline GABA & $\gamma$-Aminobutyric acid \\
\hline GFP & Green fluorescent protein \\
\hline
\end{tabular}

Special issue: In honor of Graham Collingridge.

Elek Molnár

Elek.Molnar@bristol.ac.uk

Centre for Synaptic Plasticity, School of Physiology, Pharmacology and Neuroscience, University of Bristol, Biomedical Sciences Building, University Walk, Bristol BS8 1TD, UK
GluA1-4 AMPA receptor subunit 1-4

GluK1-5 According to the new IUPHAR nomenclature the KAR subunits that were formerly known as GluR5-7 (or GLUK5-7) are now named GluK1-3 and those previously called KA-1 and KA-2 (or GLUK1 and GLUK2) are now named GluK4 and GluK5.

$\left[{ }^{3} \mathrm{H}\right] \mathrm{MG} \quad\left[{ }^{3} \mathrm{H}\right]-(2 S, 4 R)-4-$ methylgutamate

iGluR Ionotropic glutamate receptor

HEK Human embryonic kidney

KA Kainate, $(2 S, 3 S, 4 S)$-3-carboxymethyl-4-isopropenyl-pyrrolidine-2-carboxylic acid

KAR Kainate receptor

LBD Ligand binding domain

NMDA N-Methyl-D-aspartate

WT Wild type 


\section{Introduction}

Kainate receptors (KARs) are members of the ionotropic glutamate receptor (iGluR) family [1, 2]. Presynaptically KARs modulate neurotransmitter (glutamate, GABA) release, postsynaptically they contribute to the slow component of excitatory postsynaptic current (EPSC), thereby influencing neuronal excitability and network dynamics $[1,3]$. In addition to ionotropic activities, KARs exert their effects through metabotropic signalling pathways [4]. There are five KAR subunits: GluK1-5 (previously GluR5-7, KA-1 and KA-2) with different functional roles. Each subunit contributes to the formation of the KAR channel pore and contains a unique ligand binding domain (LBD) [5] with distinctive pharmacological properties [6]. The majority of native KARs are tetramers, made up of heteromeric combinations of GluK1-5 subunits [7]. Glutamate binding to the LBD triggers the opening of the KAR ion channel, which is permeable to $\mathrm{Na}^{+}$and $\mathrm{K}^{+}[6]$. Q/R editing in the channel pore forming domains of GluK1 and GluK2 determines the $\mathrm{Ca}^{2+}$ permeability of KARs [8]. KAR localisation at the cell surface is regulated by trafficking motifs for endoplasmic reticulum (ER) retention and ER export, alternative splicing, editing, associated proteins, post-translational modifications and actions of pharmacological and molecular chaperones [9, 10]. GluK1-3 traffic to the cell surface in both homo and heteromeric forms. However, GluK4 and GluK5 possess ER retention signals which are only alleviated in heteromeric assemblies with GluK1-3 [11-13]. Disruption of ligand binding to GluK2 leads to intracellular retention of subunits [14]. However, subunits with impaired LBD are able to assemble with other wild type (WT) KAR subunits with functional LBD, which enables their trafficking to the cell surface [14-16]. It has been proposed, that ligand binding in the ER is required for ER exit [17]. While functional activation of KARs may not be required, it is likely that glutamate binding induced conformational changes are necessary during biosynthesis and trafficking [14-17]. For example, the link between desensitization and ER exit has been made with KAR mutants, where engineered disulfide bridges across the ligand binding domain interface blocked GluK2 desensitization and retained mutant receptors in the ER [18].

Various KAR subunits have been implicated in different neurological and psychiatric disorders (e.g. temporal lobe epilepsy [19-21], autism [22, 23], mental retardation [24], migraine [25], schizophrenia [26], depression [27] and bipolar disorder [28]). The involvement of KARs in these pathological conditions and the possible underlying cellular and molecular mechanisms are discussed in recent reviews [3,29-31]. Therefore, KAR subunit selective ligands could have therapeutic potential [6]. The availability of crystal structures of KARs $[5,6]$ and the identification of key amino acid residues that are responsible for specific pharmacological properties of subunits [32] created new opportunities for the production of novel ligands [33-35]. However, the development of selective and potent compounds and their functional characterisation require functional expression of recombinant KAR subunits in cell lines for electrophysiological analysis or fluorescence-based screening assays using fluorescent $\mathrm{Ca}^{2+}$ indicators $[6,36,37]$. Previous studies typically used homomeric GluK1, GluK2 or GluK3 KARs expressed in human embryonic kidney 293 (HEK293) cells to test the subunit selectivity and pharmacological properties of new ligands [6, 33]. Due to the ER retention of GluK4 and GluK5 homomers, it was not possible to test their specific pharmacological characteristics in cell-based functional assays. Furthermore, there are indications that the agonist and antagonist sensitivity of heteromeric receptors can differ from recombinant homomeric KARs [38]. Therefore, testing the pharmacological properties of various KAR subunit ligand binding sites in heteromeric assemblies would be advantageous. Due to the presence of different functional LBDs in a heteromeric KAR assembly, studying the pharmacological characteristics of a specific ligand biding site in isolation and testing the subunit selectivity of a drug is very challenging.

Because each KAR subunit possesses its own ligand binding site, we hypothesised that using site-directed mutagenesis to disable the ligand binding to one subunit in a heteromer would allow the pharmacological investigation of the intact LBD in another subunit. This approach would be particularly advantageous for the development of GluK4 and GluK5 selective ligands using cell-based assays, because these subunits do not form functional KARs on their own due to their ER retention [6,11-13]. In this study we analysed changes in the biosynthesis, stability, cells surface expression and agonist-induced responses of homomeric and heteromeric KARs with various LBD mutations to examine the interplay between different ligand binding sites.

\section{Materials and Methods}

\section{Analysis of the Ligand Binding Sites}

The X-ray crystal structure of the rat GluK2 LBD in complex with kainate (Protein Data Bank identification code 1TT1 [39]) was used as a template for homology modelling of the GluK1 and GluK3 subunit ligand binding sites using SWISS-MODEL and the resultant models were examined using Accelrys DS Visualizer 3.1 (Accelrys, Inc. San Diego, CA) [32]. The residues in the GluK2 LBD that are important 
for agonist binding were mapped onto the LBDs of GluK1 and GluK3 using linear sequence alignment to determine homologous binding site residues within these subunits. Similar methodology was used starting from the X-ray crystal structure of the rat GluK1 LBD in complex with the GluK1 selective antagonist UBP310 to determine equivalent residues that would be involved in antagonist binding in the LBDs of GluK2 and GluK3 (see [32] for details). Residue numbering used excludes the signal peptide.

\section{Mutagenesis}

The desired mutations of the human GluK1-2a(Q), GluK2a(Q) and GluK3a subunit encoding cDNAs were generated using the QuickChange II XL site directed mutagenesis kit (Stratagene, La Jolla, CA) following the protocol recommended by the manufacturer. Mutations were confirmed by full-length sequencing (Geneservice, Oxford, UK).

\section{Cell Culture and Transfection}

HEK293 cells were grown in Dulbecco's modified Eagles medium (DMEM, Sigma, Gillingham, UK) containing 10\% (v/v) fetal bovine serum (Biosera, Uckfield, East Sussex, UK), $100 \mu \mathrm{g} / \mathrm{ml}$ penicillin, $100 \mu \mathrm{g} / \mathrm{ml}$ streptavidin and $2 \mathrm{mM}$ L-glutamine (all from Invitrogen Ltd., Paisley, UK) at $37^{\circ} \mathrm{C}$ in a humidified atmosphere of $5 \% \mathrm{CO}_{2}$. For passaging, cells were washed three times in PBS $(150 \mathrm{mM} \mathrm{NaCl}, 2.6 \mathrm{mM}$ $\mathrm{KCl}, 10 \mathrm{mM} \mathrm{Na} 2 \mathrm{PO}_{4}, 1.9 \mathrm{mM} \mathrm{KH}_{2} \mathrm{PO}_{4}, \mathrm{pH}$ 7.4), detached in trypsin and resuspended in DMEM for plating. Cells were transiently transfected using linear polyethylene as described previously [32] and harvested $24 \mathrm{~h}$ following transfection.

\section{Preparation of Membrane Fractions}

Membrane fractions prepared from transiently transfected HEK293 cells were harvested in $10 \mathrm{mM} \mathrm{NaHCO}_{3}$ with complete protease inhibitor cocktail (Roche Diagnostics GmbH, Mannheim, Germany). Cells were lysed using an ultrasonic cell disruptor $(2 \times 10 \mathrm{~s}$ bursts at $10 \mathrm{~W}$ on ice; Microson, Qsonica, LLC., Newtown, CT, USA). Cell homogenates were centrifuged $\left(1095 \times g, 20 \mathrm{~min}, 4{ }^{\circ} \mathrm{C}\right)$ to remove cellular debris. From the supernatants, membranes were pelleted at $40,000 \times g$ for $20 \mathrm{~min}$ at $4{ }^{\circ} \mathrm{C}$. For radioligand binding assay, membranes were washed three times using repeated resuspension in $50 \mathrm{mM}$ Tris ( $\mathrm{pH}$ adjusted to 7.2 using citric acid) and centrifugation $\left(40,000 \times g, 20 \mathrm{~min}, 4^{\circ} \mathrm{C}\right)$. Protein concentrations were measured using a protein assay kit (BioRad Laboratories, Hemel Hempstead, UK) before membrane fractions were snap frozen in liquid nitrogen and stored at $-80^{\circ} \mathrm{C}$.

\section{Radioligand Binding Assay}

For radioligand binding assays using filtration with a Brandel cell harvester (model M-30; Brandel, Gaithersburg, MD, USA) [32], membranes were diluted in binding buffer (50 mM Tris buffered with citric acid, $\mathrm{pH}$ 7.2). Membrane proteins $(150 \mu \mathrm{g})$ were incubated for $45 \mathrm{~min}$ with varying concentrations of $\left[{ }^{3} \mathrm{H}\right]$ kainate $(37 \mathrm{MBq} / \mathrm{ml}$; PerkinElmer Life and Analytical Sciences, Waltham, MA) or $\left[{ }^{3} \mathrm{H}\right]-(2 S, 4 R)-4-$ methylgutamate $\left(\left[{ }^{3} \mathrm{H}\right] \mathrm{MG} ; 50.6 \mathrm{Ci} / \mathrm{mmol}\right.$; Tocris Cookson, Bristol, UK) on ice. Kainate (1 mM) or glutamate $(1 \mathrm{mM})$ was added to parallel samples to determine nonspecific binding. Following rapid washing with binding buffer $(3 \times 4 \mathrm{ml})$, the radioactivity of filters was measured using a liquid scintillation counter (LS6500, Beckman High Wycombe, UK).

\section{Endoglycosidase Digestion}

Membrane fractions prepared from transiently transfected HEK293 cells were solubilised in 1\% Triton X-100 and $0.1 \%$ SDS in phosphate buffered saline (PBS; $150 \mathrm{mM}$ $\mathrm{NaCl}, 2.6 \mathrm{mM} \mathrm{KCl}, 10 \mathrm{mM} \mathrm{Na} 2 \mathrm{PO}_{4}, 1.9 \mathrm{mM} \mathrm{KH}_{2} \mathrm{PO}_{4}, \mathrm{pH}$ 7.4). Samples were centrifuged $\left(21,255 \times g, 15 \mathrm{~min}, 4^{\circ} \mathrm{C}\right)$ to remove debris. Endoglycosidase $\mathrm{H}$ (EndoH, $5 \mathrm{mU} / 100 \mu \mathrm{l}$ of sample) or endoglycasidase F (EndoF; $1 \mathrm{U} / 100 \mu \mathrm{l}$ of sample; Roche Diagnostics GMBH, Mannheim, Germany) were added to equal aliquots of solubilised membrane samples and incubated overnight at $37^{\circ} \mathrm{C}$ [40] before immunoblot analysis.

\section{Cell Surface Biotinylation}

Transfected HEK293 cells were washed three times with PBS and incubated for $30 \mathrm{~min}$ in EZ-link sulfo-NHS-S$S$-biotin $(0.5 \mathrm{mg} / \mathrm{ml}$; Pierce Biotechnology, Rockford, IL, USA) as described previously [11, 41]. Membrane fractions prepared from cell surface biotinylated cultures were solubilised in lysis buffer ( $1 \%$ triton X100, $0.5 \%$ deoxycholic acid, $0.1 \%$ SDS, 1 mM EDTA, $100 \mathrm{mM} \mathrm{NaCl}, 50 \mathrm{mM}$ Tris-HCl, pH 7.4 with complete protease inhibitor cocktail; Roche Diagnostics GmbH, Mannheim, Germany). Cellular lysates were centrifuged $\left(21,255 \times \mathrm{g}, 15 \mathrm{~min}, 4^{\circ} \mathrm{C}\right)$ and $1 / 10$ th of the supernatant containing the solubilised membranes was used for acetone precipitation of proteins. To separate biotinylated cell surface and non-biotinylated intracellular proteins, the remaining fraction of lysate was incubated with a 1:1 mixture of streptavidin agarose beads (Sigma-Aldrich Company Ltd., Gillingham, Dorset, UK) for $3 \mathrm{~h}$ at $4{ }^{\circ} \mathrm{C}$ with mixing by rotation. Beads were washed in lysis buffer and $50 \mathrm{mM}$ Tris- $\mathrm{HCl}(\mathrm{pH} 7.5$ ) before biotinylated cell surface proteins were eluted by heating $\left(100^{\circ} \mathrm{C}\right.$ for $\left.2 \mathrm{~min}\right)$ in SDSpolyacrylamide gel electrophoresis (SDS-PAGE) sample 
buffer (2\% (w/v) SDS, 50 mM Tris-HCl (pH 6.8), 10\% $(\mathrm{v} / \mathrm{v})$ 2-mercaptoethanol, $10 \%(\mathrm{v} / \mathrm{v})$ glycerol and $0.1 \%(\mathrm{w} / \mathrm{v})$ bromophenol blue) [11]. The $\beta$-actin content of biotinylated fractions was analysed on immunoblots to confirm that no intracellular proteins were labelled with biotin.

\section{Cycloheximide Treatment of Cells}

Twenty-four hours after transfection, HEK293 cells were treated with the protein synthesis blocker cycloheximide (50 $\mu \mathrm{g} / \mathrm{ml}$; Sigma-Aldrich Company Ltd., Gillingham, Dorset, UK) to investigate potential differences in the degradation of wild type (WT) and mutant KARs subunits. Sister cultures were harvested at $0,4,8,12,24$ and $36 \mathrm{~h}$ after the addition of cycloheximide and KAR subunit proteins were analysed in cell membrane lysates using immunoblotting as described previously [40].

\section{Immunoblot Analysis}

Following solubilisation in SDS-PAGE sample buffer, equal aliquots of proteins (10-20 $\mu \mathrm{g} / \mathrm{lane})$ were separated on $8 \%$ (w/v) SDS-PAGE gels and electrophoretically transferred onto polyvinylidene difluoride membranes [11]. Blots were probed with $0.1-0.5 \mu \mathrm{g} / \mathrm{ml}$ previously validate immunoaffinity purified polyclonal rabbit antibodies to GluK1 [32], GluK2/3 [42], GluK5 [42, 43] (Millipore, Watford, UK) and mouse monoclonal anti- $\beta$-actin antibody (Abcam, Cambridge, UK). Previously described protocol was used to establish the linear sensitivity range of immunoreactivities for quantification using enzyme chemiluminescence (ECL) [44]. For the quantitative comparison of total KAR subunit levels, immunoreactivities were normalised to the $\beta$-actin content of each sample.

\section{Measurements of $\left[\mathrm{Ca}^{2+}\right]_{\mathrm{i}}$}

Changes in intracellular $\mathrm{Ca}^{2+}$ concentration $\left[\mathrm{Ca}^{2+}\right]_{\mathrm{i}}$ were measured by following changes in $\mathrm{Ca}^{2+}$-sensitive dye (fura-2-AM; Sigma) fluorescence. Green fluorescent protein (GFP) co-expression was used to enable the identification of cells that express KAR subunits $(\sim 12 \%)$. Transfected HEK293 cells, that had been maintained for $24 \mathrm{~h}$, were washed three times in HEPES buffered saline (HBS; $135 \mathrm{mM} \mathrm{NaCl}, 5 \mathrm{mM} \mathrm{KCl}, 10 \mathrm{mM}$ HEPES, $1 \mathrm{mM} \mathrm{MgCl}$, $2 \mathrm{mM} \mathrm{CaCl}_{2}, 30 \mathrm{mM}$ glucose, $\mathrm{pH} \mathrm{7.4)} \mathrm{at} 37{ }^{\circ} \mathrm{C}$ and loaded with $5 \mu \mathrm{M}$ fura-2-AM in HBS for $45 \mathrm{~min}$ at $37{ }^{\circ} \mathrm{C}$. Cells were than washed again in HBS three times and incubated for $15 \mathrm{~min}$ in the dark at room temperature (about $20^{\circ} \mathrm{C}$ ). Imaging was carried out using a continuous flow of HBS $\left(2 \mathrm{ml} / \mathrm{min}\right.$ at $20^{\circ} \mathrm{C}$ ) with a wash time of $5 \mathrm{~min}$ followed by addition of carbachol $(10 \mu \mathrm{M})$ and kainate $(25 \mu \mathrm{M}$; Tocris Bioscience, Bristol, UK) in the presence of the KAR desensitisation blocker concanavalin A (ConA; $0.3 \mathrm{mg} / \mathrm{ml}$; Sigma [45]) for 5 min with a 10 min wash in between drugs. Cells were visualised through a $\mathrm{x} 20$ objective on a Nikon eclipse TE2000-S microscope and a Hamatsu ORCA-ER camera (Hamatsu Photonics, Welwyn Garden City, UK). For ratiometric measurements, the emission at $510 \mathrm{~nm}$ was measured at $5 \mathrm{~s}$ intervals during alternate excitation at $340 \mathrm{~nm}$ and $380 \mathrm{~nm}$ for $200 \mathrm{~ms}$, by a Lamda DG-4 light source and wavelength switcher (Sutter Instrument, Novato, CA, USA). The ratio of intensity of the emission at $340 \mathrm{~nm}$ and $380 \mathrm{~nm}$ (340/380 ration) was calculated by the Volocity software (PerkinElmer, Coventry, UK) and used as a measure of $\left[\mathrm{Ca}^{2+}\right]_{\mathrm{i}}$. Matlab (Mathworks, Cambridge, UK) was used to calculate whether individual cells responded to kainate or carbachol. A positive response was recorded when $340 / 380$ ratio was more than twice the standard deviation of the baseline measured immediately before drug application.

\section{Statistics}

Statistical analysis was performed using an unpaired Student's $t$ test. The ' $n$ ' represents the number of independent experiments. For non-equal ' $n$ ' numbers, a two-sample equal variance $t$ test was performed. A ' $p$ ' value of less than 0.05 was considered significant $(*)$ and less than 0.02 was considered highly significant $(* *)$. Results are presented as mean \pm SEM

\section{Results}

\section{Identification of Residues in GluK1-3 Subunits that are Involved in Ligand Binding}

To identify conserved residues within the ligand binding domains (LBDs) of GluK1-3 subunits that are critical to glutamate binding, high resolution crystal structures of the GluK1 and GluK2 S1S2 domains [39] were analysed (Fig. 1). These models predicted that conserved amino acid residues in the GluK2 S1 domain (GluK2-A487) and GluK1-3 S2 domains (GluK1-T675, GluK2-T659 and GluK3-T661) are important for agonist binding. Mutation of these residues would interfere with glutamate binding, by creating steric clashes (GluK2-A487L; Fig. 1a) or through the loss of a hydrogen bond (GluK1-T675V; Fig. 1b). Steric occlusion in the GluK2-A487L mutant is achieved by replacing the methyl group of GluK2-A487 with a bulkier isobutyl group via replacement with a leucine residue, which extends deeper into the binding cavity, thereby preventing agonist binding. The hydroxyl group of GluK1-T675 forms an important hydrogen bond with the distal carboxylate of agonists such as glutamate and kainate and its replacement 
Fig. 1 Identification of amino acid residues critical to agonist binding. Molecular modelling based on the crystal structures of the S1S2 ligand binding domains of GluK1 and GluK2 in complex with glutamate (purple) [39] was used to generate mutant subunits with impaired ligand binding sites. a It was predicted that glutamate binding can be prevented through the introduction of steric clashes by changing an Ala residue in the S1 domain of GluK2 (GluK2-A487) to a bulkier Leu (green molecule). b Modelling indicated that glutamate forms a hydrogen bond (green dotted line in red circle) with a Thr residue (green) in the $\mathrm{S} 2$ domain of GluK1 (GluK1-T675), which can be disrupted by mutating this residue to Val. (Color figure online)
A GluK2

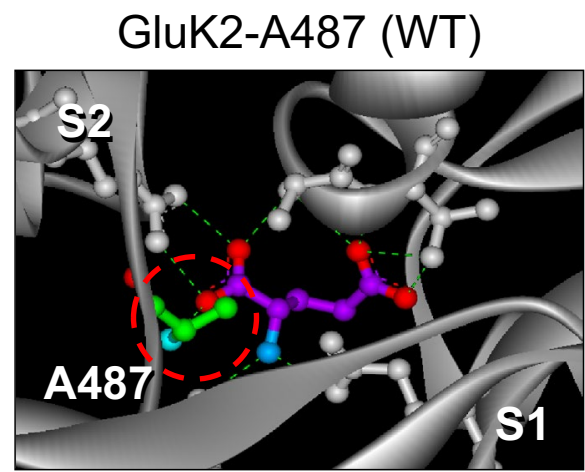

$\downarrow$ GluK2-A487L mutant

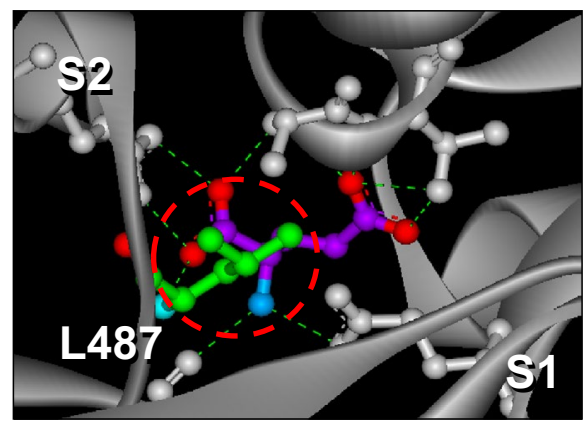

Steric clashes induced
B GluK1
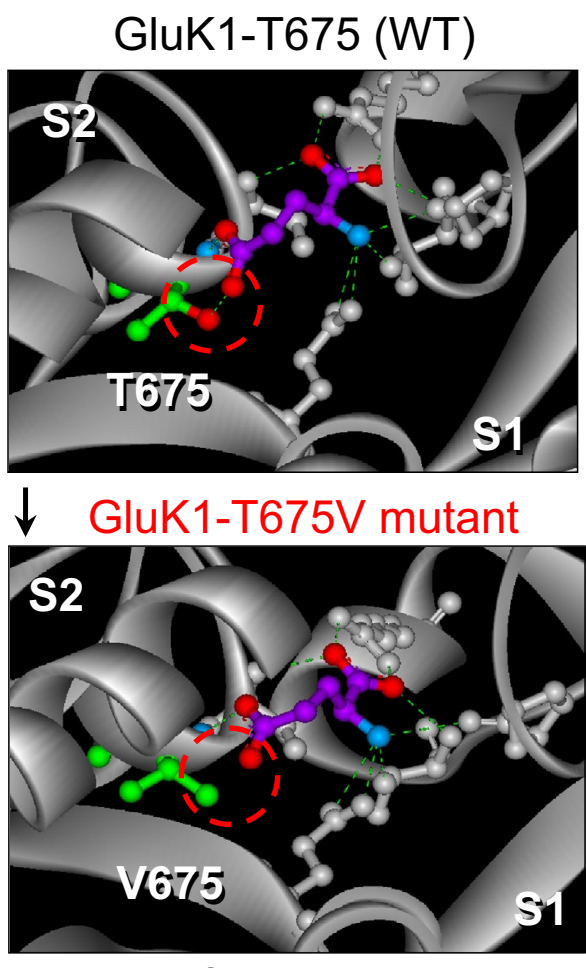

Loss of hydrogen bond with a methyl group in the GluK1-T675V mutant would therefore be expected to drastically reduce agonist affinity.

The identification and characterisation of non-conserved amino acid residues in the GluK1-3 S1 domains (GluK1T503, GluK2-A487 and GluK3-T489) and S2 domains (GluK1-S706, GluK2-N690 and GluK3-N691) that determine antagonist subunit selectivity without blocking agonist binding to the receptor (Fig. 2) has been described in our previous study [32]. While the swapping of these nonconserved residues between GluK1-3 converts the antagonist selectivity of subunits, glutamate and kainate binding is retained [32]. Therefore, these mutants that convert subunitselective characteristics of GluK1-3 LBDs (Fig. 2; [32]) together with wild type (WT) KAR subunits were used as controls in this study.

\section{Mutation-Induced Changes in $\left[{ }^{3} \mathrm{H}\right]$ kainate and $\left[{ }^{3} \mathrm{H}\right]$ MG Binding to GluK1-3}

To establish if the mutations that were introduced based on the crystal structure analysis had the desired effects on the agonist binding properties of mutant GluK1-3 KAR subunits (Fig. 2), radioligand binding assays were performed using $\left[{ }^{3} \mathrm{H}\right]$ kainate and $\left[{ }^{3} \mathrm{H}\right] \mathrm{MG}$ (Fig. 3). Mutations of conserved residues in the GluK1-3 LBDs (GluK1-T675V,
GluK2-A487L, GluK2-T659V and GluK3-T661V) significantly reduced both $\left[{ }^{3} \mathrm{H}\right]$ kainate (Fig. 3a) and $\left[{ }^{3} \mathrm{H}\right] \mathrm{MG}$ (Fig. 3b) binding activities. In contrast, exchanging A/T nonconserved amino acid residues in GluK1 (GluK1-T503A) and GluK2 (GluK2-A487T) (Fig. 2b) produced no change in ligand binding activity compared to the corresponding WT subunits (Fig. 3a). The $\left[{ }^{3} \mathrm{H}\right]$ kainate binding activities of GluK1-N705S/S706N, GluK2-S689N/N690S and GluK3N691S were shifted from the parent subunit towards that of the subunit the mutation was designed to imitate (Fig. 3a; [32]). These experiments confirmed that mutation of GluK1T675, GluK2-A487, GluK2-T659 and GluK3-T661 disrupts agonist binding.

\section{Changes in the Expression Levels of Ligand Binding Site Mutant GluK1-3 Subunits}

Expression levels of WT and LBD mutant GluK1-3 subunit proteins (Fig. 2) were assessed $24 \mathrm{~h}$ after transient transfection of HEK293 cells using immunoblot analysis (Fig. 4a). Previously characterised GluK1 [32] and GluK2/3 [11, $32,40,42]$ specific antibodies were used for the identification of KAR subunits (Fig. 4a). While the expression levels of GluK1-3 subunits with functional LBDs (GluK1N705S/706N, GluK1-T503A, GluK2-S689N/N690S, 
Fig. 2 Mutation of key amino acid residues in the S1S2 ligand binding domains of GluK1-3. a Schematic model of kainate receptor (KAR) subunit with the S1S2 ligand binding sites and M1-4 membrane domains. Glu glutamate, $N$ amino-terminus, $C$ carboxy-terminus, $E C$ extracellular, $I C$ intracellular. Insert illustrates membrane domains in the KAR ion channel, which is formed by four subunits. $\mathbf{b}$ Mutations in the S1S2 ligand binding sites of GluK1-3 that disrupt glutamate (Glu) binding (red) or convert subunit selective characteristics of GluK1-3 without blocking Glu binding (blue; [32]). (Color figure online)

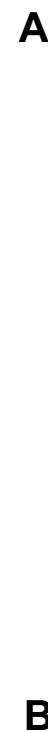

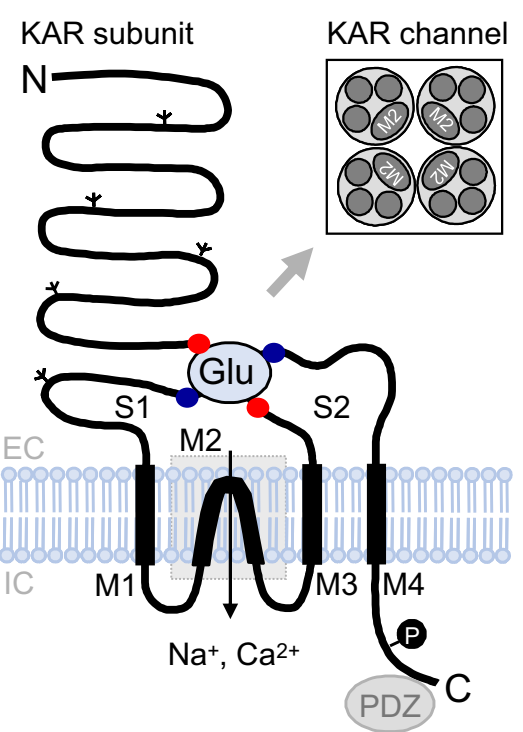

Mutations of conserved residues that are critical to Glu binding

GluK2 A487L
GluK1 T675V
GluK2 T659V
GluK3 T661V

S1

GluK1 666-EYGAVRDGSTMTFFKKSKIST-686
-------V---------
GluK2 650-EYGAVEDGATMTFFKKSKIST-670
--------V--------
GluK3 652-EYGAVKDGATMTFFKKSKIST-672
-------V---------

S2

Exchange of non-conserved residues that convert subunit selectivity

GluK1 T503A
GluK2 A487T
GluK3 T489A

GluK1 N705S/S706N

GluK2 S689N/N690S

GluK3 N691S

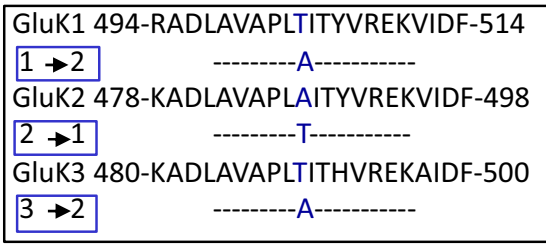

S1

\begin{tabular}{|l|l|}
\hline GluK1 697-RQQSALVKNSDEGIQRVLTTD-717 \\
\hline $1 \rightarrow 2$ \\
\hline GluK2 681-RRQSVLVKSNEEGIQRVLTSD-701 \\
$2 \rightarrow 1$ \\
$\begin{array}{l}\text { GluK3 682-SKPSALVKNNEEGIQRTLTAD-703 } \\
3 \rightarrow 1\end{array}$ \\
\hline 3
\end{tabular}

S2
GluK2-A487T and GluK3-N691S) were similar to WT, there was a marked reduction in the level of subunits with impaired ligand binding (GluK1-T675V, GluK2-A487L, GluK3-T661V; Fig. 4b). Investigation of the degradation rates of different LBD mutant GluK1-3 subunits (Fig. 2) using cycloheximide treatment [40] indicate no significant differences at any of the investigated time points (4, 8, 12, 24 and $36 \mathrm{~h}$ following the addition of cycloheximide) compared to WT (not shown). These experiments indicate that there is a significant reduction in the level of GluK1-3 subunits with impaired ligand binding sites and this does not appear to be caused by increased degradation.

\section{Comparison of Intracellular Trafficking of GluK1-3 Containing Homomeric Wild-Type and Ligand Binding Site Mutant KARs}

Previous studies reported that LBD mutations that impair glutamate binding or prevent conformational changes can prevent the export of KAR subunit proteins to the cell 

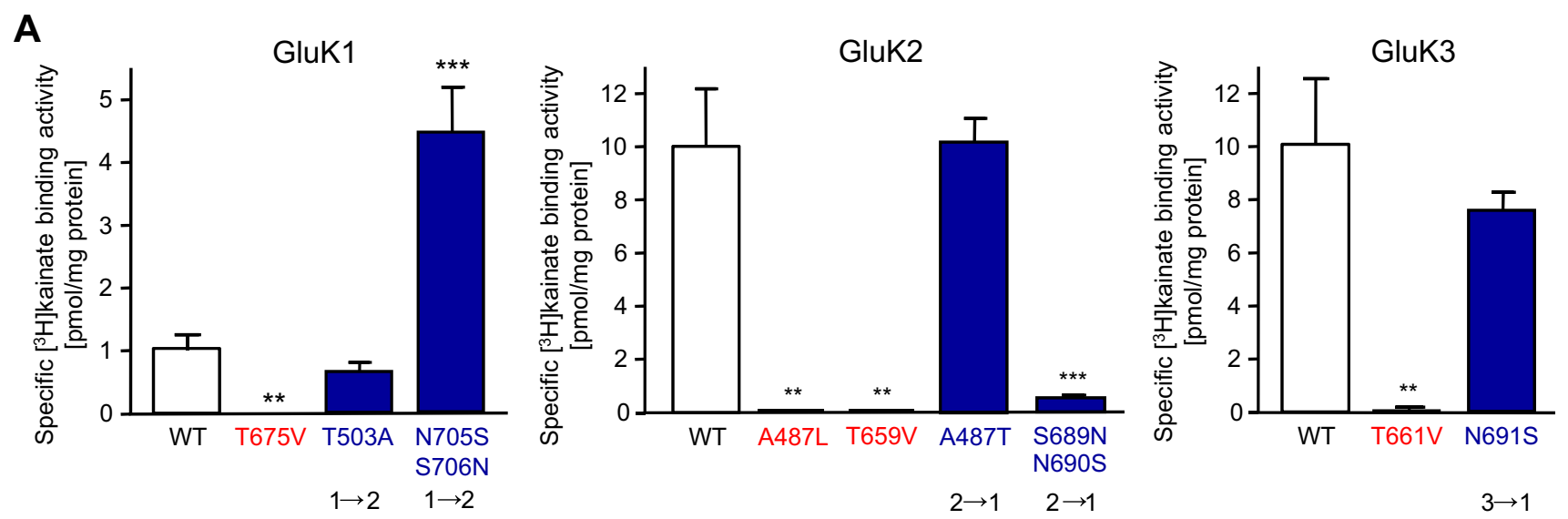

B
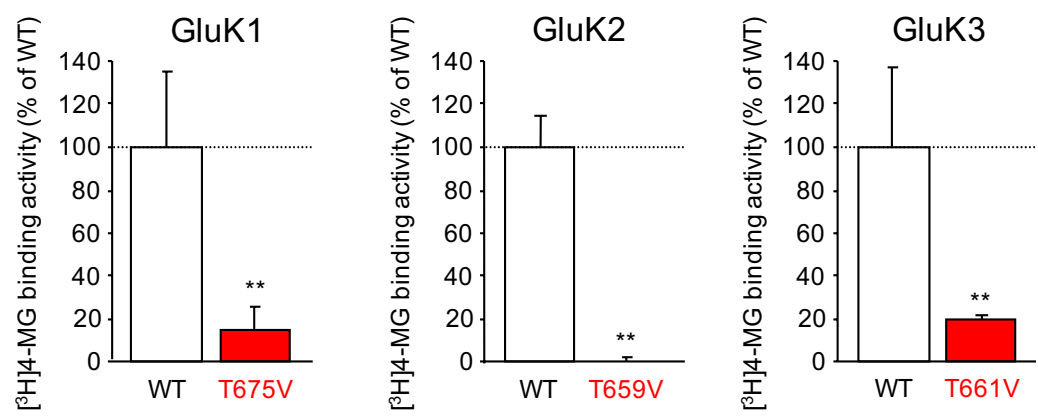

Fig. 3 Modification of conserved amino acid residues within the GluK1-3 S1S2 domains disrupts agonist binding. HEK293 cells were transiently transfected with wild type (GluK1-WT, GluK2-WT, GluK3-WT) or LBD mutant (GluK1-T675V, GluK1-T503A, GluK1N705S/S706N, GluK2-A487L, GluK2-T659V, GluK2-A487T, GluK2-S689N/N690S， GluK3-T661V， GluK3-N691S) GluK1-3 KAR subunit containing plasmids. After $48 \mathrm{~h}$ membranes were isolated and thoroughly washed by centrifugation and resuspension, before the radioligand binding assay was carried out. The presence of KAR subunits in membrane samples was confirmed using immunoblotting (not shown). Membrane fractions (150 $\mu$ g protein/assay) were incubated with $100 \mathrm{nM}\left[{ }^{3} \mathrm{H}\right]$ kainate in the presence (non-specific binding) and the absence (total binding) of $1 \mathrm{mM}$ kainate a or $10 \mathrm{nM}$ $\left[{ }^{3} \mathrm{H}\right]-(2 \mathrm{~S}, 4 \mathrm{R})-4-m e t h y l g u t a m a t e\left(\left[{ }^{3} \mathrm{H}\right] \mathrm{MG}\right)$ in the presence (non-spe-

surface $[17,46]$. Therefore, we compared the trafficking of WT and LBD mutant homomeric GluK1-3 KARs by analysing their glycosylation status by EndoH and EndoF digestion (Fig. 5) and cell surface biotinylation (Fig. 6). Our previous studies established that EndoH resistance directly correlates to cell surface expression of KARs and can be used to monitor the processing of glycosylated subunits during their trafficking through the secretory pathway in transfected HEK293 cells and neurons [32, 40]. Therefore, we compared the EndoH resistant (higher molecular weight) KAR subunit protein bands that indicates trafficking through the Golgi, to EndoH sensitive (deglycosylated lower molecular weight) bands that represent ER-retained subunits (Fig. 5). Due to the endoplasmic reticulum retention of WT GluK1 [9], cific binding) and the absence (total binding) of $1 \mathrm{mM}$ glutamate (b). While the mutation of conserved residues (GluK1-T675V, GluK2A487L, GluK2-T659V, GluK3-T661V) resulted a marked reduction in $\left[{ }^{3} \mathrm{H}\right]$ kainate (a) and $\left[{ }^{3} \mathrm{H}\right] \mathrm{MG}$ (b) binding, exchanging residues between GluK1 and GluK2 at the T/A site of the S1 domain (GluK1T503A, GluK2-A487T) produced no significant change in $\left[{ }^{3} \mathrm{H}\right] \mathrm{kain}-$ ate binding. The exchange of N/S residues at the $\mathrm{S} 2$ domain increased $\left[{ }^{3} \mathrm{H}\right]$ kainate binding to GluK1-N705S/S706N and reduced the binding activity of GluK2-S689N/N690S and GluK3-N691S. LBD mutant GluK1-3 were compared to the corresponding WT subunit. Data are mean \pm SEM $(n=3$ independent determinations using three parallel samples in each experiment); $* * p<0.01, * * * p<0.005$, Student's $t$ test

LBD mutants of this subunit (GluK1-T503A, GluK1-T675V and GluK1-N705S/S706N) displayed equally high level of EndoH sensitivity and low level of surface expression with no detectable differences between WT and mutants (Fig. 5b). As expected, $~ 50 \%$ of GluK2-WT and $~ 30 \%$ of GluK3-WT were EndoH resistant (Fig. 5), which is consistent with previous studies [32, 40]. While the EndoH/EndoF sensitivity profiles of mutant GluK2 and GluK3 with functional LBD (GluK2-S689N/N690S, GluK2-A487T, GluK3-N691S; Fig. 5) were very similar to the corresponding WT, subunits with impaired ligand binding displayed a significantly higher level of EndoH sensitivity (GluK2-T659V, GluK2-A487L, GluK3-T661V; Fig. 5). 
A GluK1 GluK2 GluK3
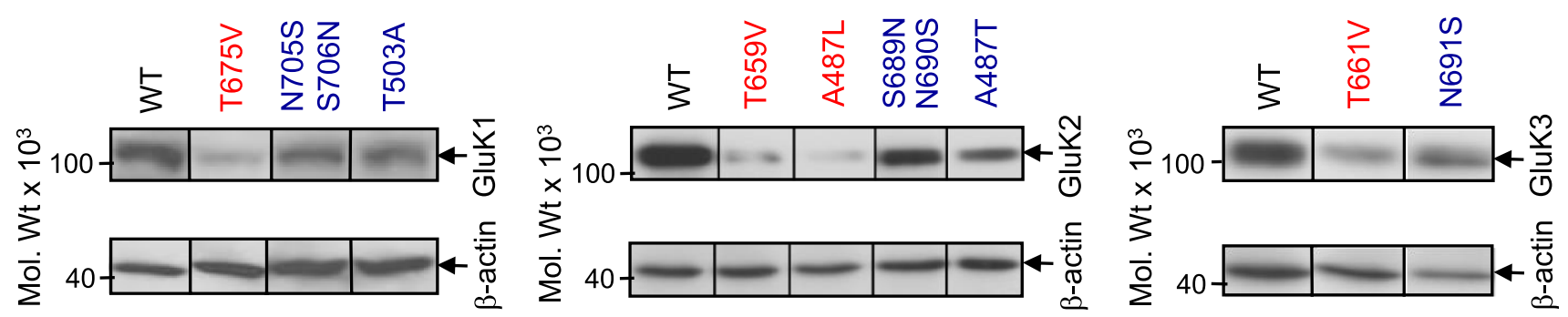

B

GluK1
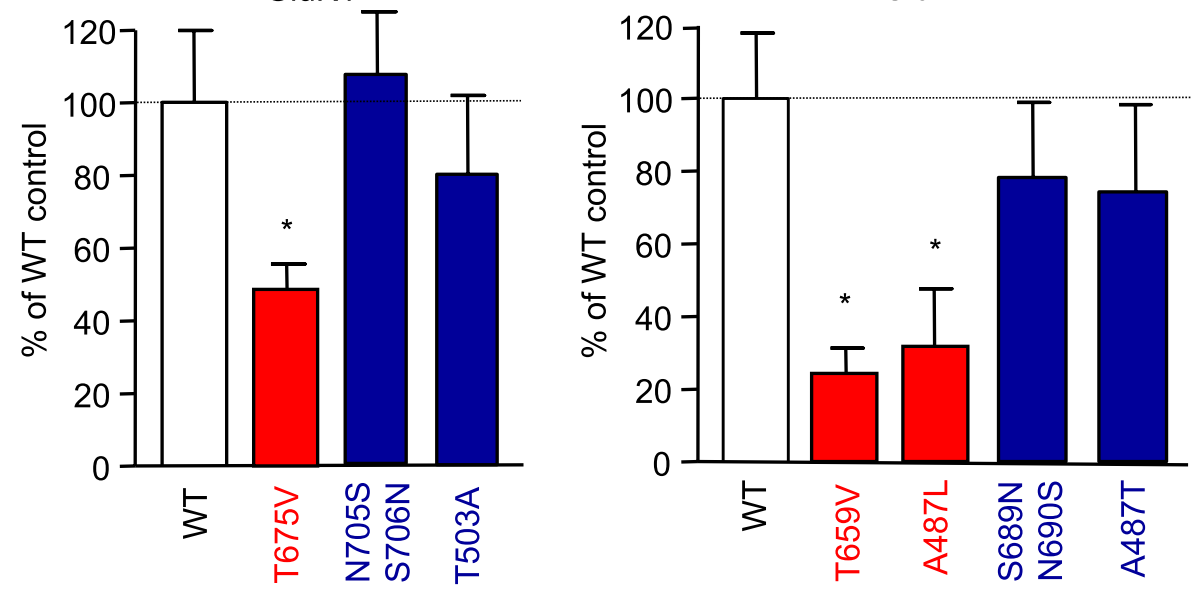

GluK3

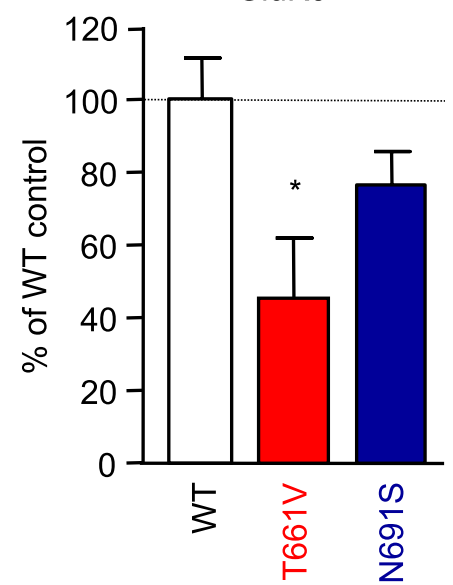

Fig. 4 Mutations that disrupt agonist binding cause reduction in KAR subunit protein levels. a Membrane fractions prepared from transiently transfected HEK293 cells $24 \mathrm{~h}$ after transfection, were analysed using immunoblotting with previously validated GluK1 and GluK2/3 subunit selective antibodies. To reveal potential quantitative differences in total KAR subunit expression levels, samples were prepared from sister cultures transfected at the same time with the various WT and mutant subunit constructs and processed in parallel for immunoblotting. ECL exposure time was adjusted to the linear sensitivity range of immunoreactivities to allow quantitative

comparisons between bands identified by the same antibody. b KAR subunit immunoreactivities were normalised to the $\beta$-actin content of the sample. Mutant GluK1-3 subunits with impaired LBDs (GluK1T675V, GluK2-T659V, GluK2-A487L; red) show a significant decrease in subunit protein levels compare to the corresponding WT (GluK1-WT, GluK2-WT, GluK3-WT; white) or other LBD mutants that retained agonist binding activity (GluK1-N705S/S706N, GluK1T503A, GluK2-S689N/N690S, GluK2-A487T, GluK3-N691S; blue). Data are mean $\pm \operatorname{SEM}(n=3-4),{ }^{*} p<0.05$, Student's $t$ test. (Color figure online)

Changes in the surface expression of WT and LBD mutant GluK2 and GluK3 homomeric KARs was confirmed by surface biotinylation of transiently transfected HEK293 cells and subsequent separation of biotin-labelled proteins by streptavidin $[11,41]$. Total $(\mathrm{T})$, biotin labelled surface (S) and unlabelled intracellular (I) protein fractions were analysed using immunoblotting [32, 40] (Fig. 6a). Cell surface expression levels were determined relative to the total KAR subunit content of the relevant samples (Fig. 6b). No immunoreactivity to $\beta$-actin was detected in the biotinylated fractions of the subunits indicating that only proteins present on the cell surface were labelled (Fig. 6a). In agreement with the EndoH sensitivity profiles, there were no significant differences between the surface expression of mutant GluK2 and GluK3 with functional LBD (GluK2-S689N/N690S, GluK2-A487T, GluK3-N691S; Fig. 6b) compared to the corresponding WT (GluK2-WT, GluK3-WT; Fig. 6b). In contrast, the cell surface expression of subunits with impaired LBD was significantly lower (GluK2-T659V, GluK2-A487L, GluK3-T661V; Fig. 6b) compared to the corresponding WT.

These experiments indicate that disruption of ligand binding to GluK2 or GluK3 prevents the cell surface expression of homomeric KARs.

\section{The Effect of GluK5 Co-expression on the Cell Surface Trafficking of GluK2 LBD Mutants}

Cell surface expression of heteromeric assemblies of GluK2 with functional (GluK2-WT, GluK2-S689N/N690S, GluK2A487T) and impaired (GluK2-T659V, GluK2-A487L) LBDs in combination with GluK5-WT was assessed using biotinylation of surface proteins in transiently transfected HEK293 cells (Fig. 7). While GluK5 alone is completely retained in the ER [11], co-expression with WT or any of 

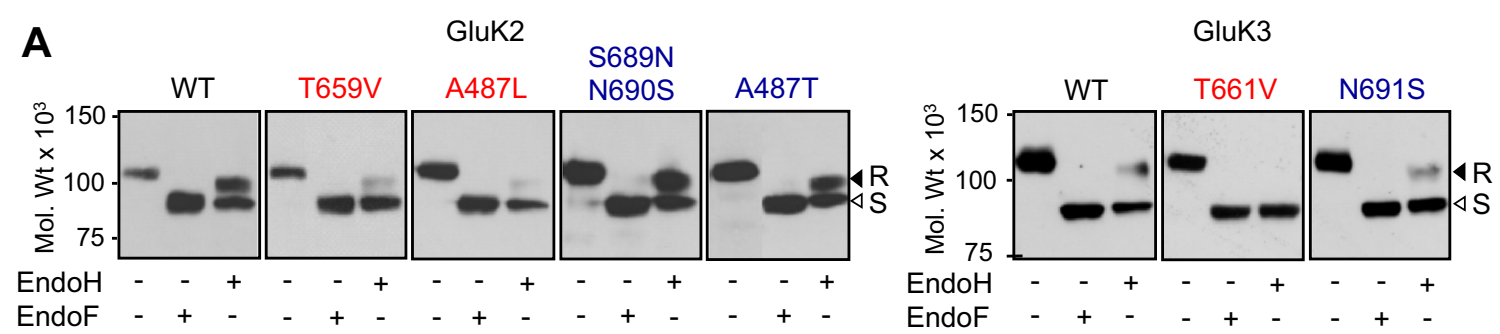

\section{B} GluK2

GluK3

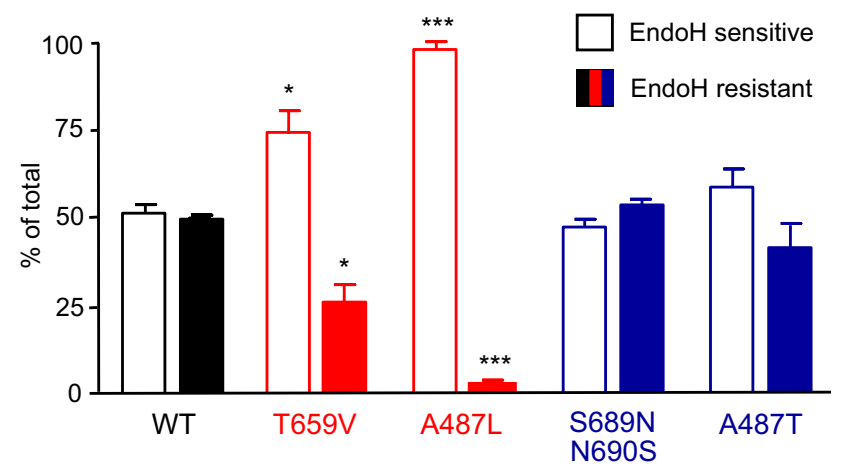

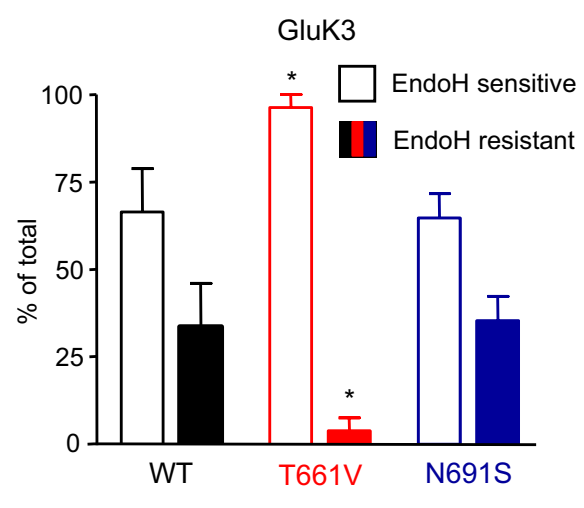

GluK1

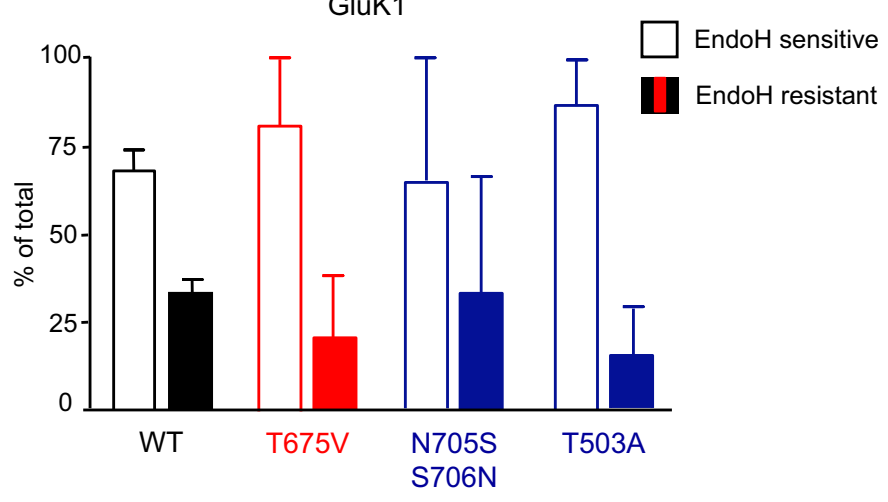

Fig. 5 Homomeric KARs with impaired LBDs are retained in intracellular compartments. a Solubilised membrane fractions obtained from transiently transfected HEK293 cells expressing WT and mutant GluK2 and GluK3 subunits for $24 \mathrm{~h}$ were deglycosylated with EndoH or EndoF as indicated and analysed using immunoblotting with a rabbit GluK2/3 specific antibody. While EndoH resistant GluK2 and GluK3 were identified around $105 \mathrm{kDa}$ (R, black arrow heads), the EndoH sensitive subunits showed a molecular weight reduction to $\sim 95 \mathrm{kDa}$ (S, white arrow heads). EndoF enzyme treatment of GluK2 and GluK3 produced a single band with molecular weight of $\sim 93 \mathrm{kDa}$. Due to the identified differences in total expression levels of various KAR subunit mutants (Fig. 4), immunodetec-

the LBD mutant GluK2 enabled the surface expression of GluK2/GluK5 heteromers.

Co-expression with GluK5-WT also increased the cell surface expression of all GluK2 variants (GluK2-WT/ GluK5-WT: 28\%/ 27\%; GluK2-T659V/GluK5-WT: 28\%/ 26\%; GluK2-A487L/GluK5-WT: 14\%/ 14\%; GluK2-S689N/N690S/GluK5-WT: 12\%/ 10\%; GluK2A487T/GluK5-WT: 18\%/ 20\%) compare to homomeric tion of bands was optimised separately for the quantitative comparison of EndoH and EndoF sensitive/resistant bands for each construct. b Mutants with impaired LBDs (GluK2-T659V, GluK2-A487L and GluK3-T661V; red) show greater EndoH sensitivity than the corresponding WT subunits. In contrast, LBD conversion mutants of GluK2 and GluK3 that retain ligand binding (GluK2-S689N/N690S, GluK2-A487T, GluK3-N691S) show no significant change in EndoH sensitivity compared to WT. There were no detectable differences in the EndoH sensitivity of GluK1-WT, GluK1-T503A, GluK1-N705S/ S706N and GluK1-T675V. Data are mean \pm SEM $(n=3),{ }^{*} p<0.05$, $* * * p<0.005$, Student's $t$ test. (Color figure online)

subunits (Fig. 6). This GluK5-WT co-expression-related increase in cell surface GluK2 was particularly prominent for mutant subunits with impaired LBD ( sevenfold for GluK2-T659V and fivefold for GluK2-A487L; Figs. 6, 7). This indicates that co-expression relieves the ER retention of both GluK5-WT and GluK2 with mutations that block ligand binding (GluK2-T690V, GluK2-A487L) and enables their cell surface trafficking as heteromers. 

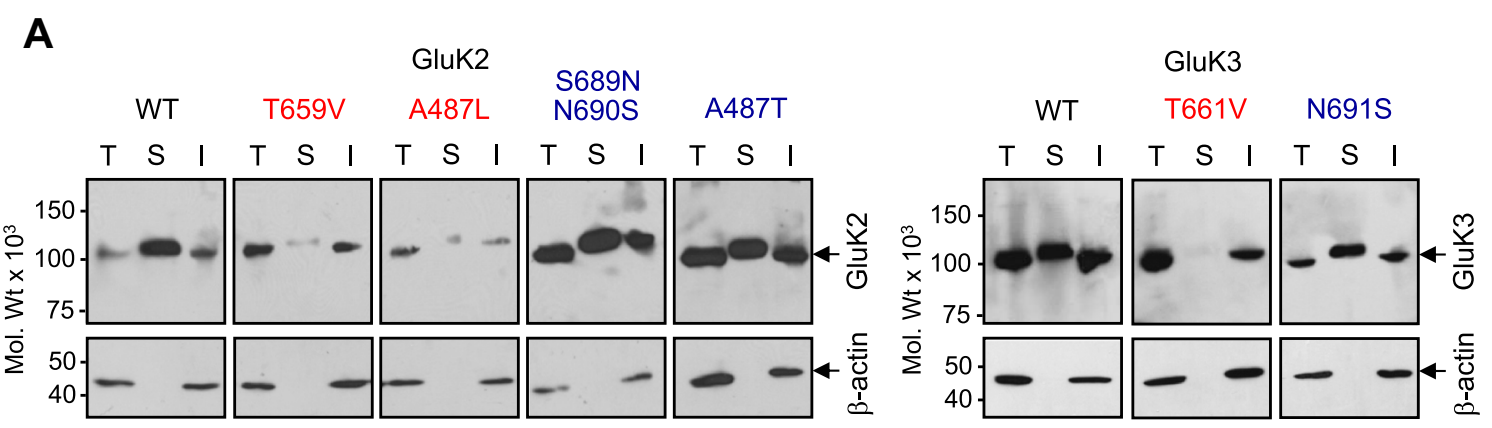

B

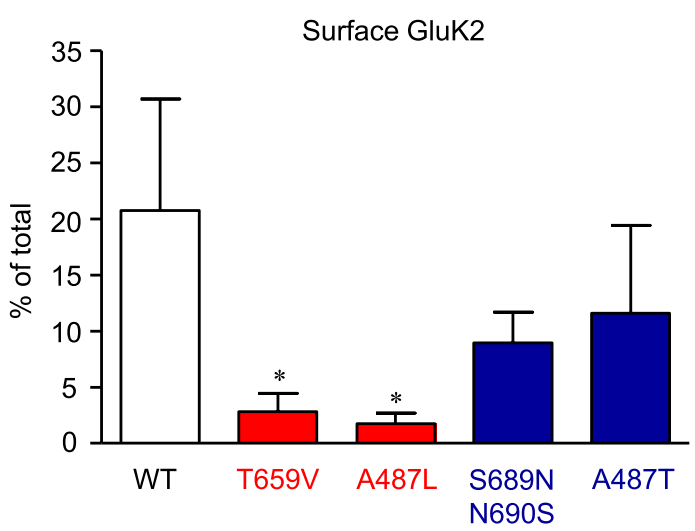

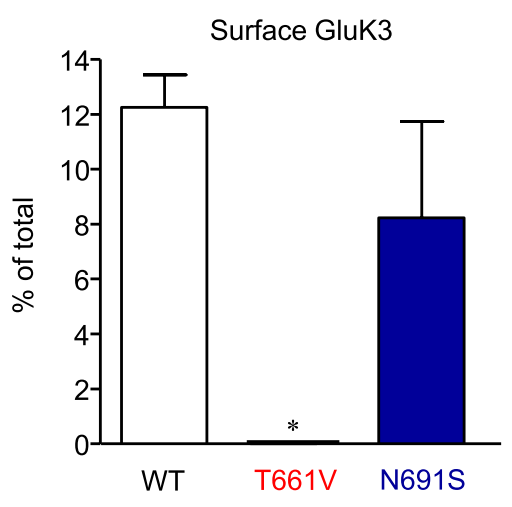

Fig. $6 \mathrm{Thr} / \mathrm{Val}$ and Ala/Leu mutations reduce cell surface expression of GluK2 and GluK3 subunit proteins. a Transiently transfected HEK293 cells expressing wild type (GluK2-WT, GluK3-WT) or mutant subunits with impaired ligand binding sites (GluK2-T659V, GluK2-A487L, GluK3-T661V; red) or conversion mutants with functional ligand binding sites (GluK2-S689N/N690S, GluK2-A487T, GluK3-N691S; blue) were surface biotinylated $24 \mathrm{~h}$ after transfection. Following the solubilisation of membranes (total; T), biotin-labelled (cell surface exposed; S) proteins were separated from non-biotinylated (intracellular; I) proteins using streptavidin coated beads. The different subunit populations were analysed using immunoblotting with a GluK2/3 specific antibody. The $\beta$-actin content of the samples was analysed to confirm that biotinylation only labelled cell surface exposed proteins in transfected HEK293 cells. Due to differences

\section{Functional Characterisation of Homomeric and Heteromeric KARs}

Kainate $(25 \mu \mathrm{M})$ induced changes in intracellular $\mathrm{Ca}^{2+}$ concentration $\left(\left[\mathrm{Ca}^{2+}\right]_{\mathrm{i}}\right)$ were analysed using a fluorescence-based assay in transiently transfected HEK293 cells expressing GluK2-WT, GluK2-T659V, GluK2A487L, GluK2-S689N/N690S or GluK2-A487T either as homomeric receptors or in combination with GluK5WT (Fig. 8). GFP was used as a marker to identify transfected HEK293 cells $(\sim 12 \%)$ that express KAR subunits. The muscarinic acetylcholine receptor agonist carbachol $(10 \mu \mathrm{M})$ was used to confirm the responsiveness of transfected cells. Following the investigation of agonist-induced $\left[\mathrm{Ca}^{2+}\right]_{\mathrm{i}}$ responses, cells were routinely in total expression levels of various KAR subunit mutants (Fig. 4), immunodetection of bands were optimised for the quantitative comparison of biotinylated and non-biotinylated (intracellular) bands for each construct. b Bar diagrams compare the biotinylated (surface) fractions of subunits expressed as \% of total. Mutants with impaired LBDs (GluK2-T659V, GluK2-A487L and GluK3-T661V; red bars) show reduced cell surface expression (biotinylation) than the corresponding WT subunits (white bars). In contrast, LBD conversion mutants of GluK2 and GluK3 that retain ligand binding (GluK2S689N/N690S, GluK2-A487T, GluK3-N691S; blue bars) show no significant change in cell-surface biotinylation compare to WT. Data are mean $\pm \operatorname{SEM}(n=3),{ }^{*} p<0.05$, Student's $t$ test. (Color figure online)

harvested for immunoblot analysis to verify the expression levels of KAR subunits. Activation (kainate, $25 \mu \mathrm{M}$ ) of mutant GluK2 subunits with functional ligand binding sites (GluK2-S689N/N690S, GluK2-A87T) produced very similar $\left[\mathrm{Ca}^{2+}\right]_{\mathrm{i}}$ responses to GluK2-WT, which was not altered significantly by the co-expression of GluK5-WT subunit (Fig. 8). This indicates that exchanging non-conserved residues that convert pharmacological properties of the GluK2 LBD but retain ligand binding [32] (Fig. 3), does not alter receptor function. In contrast, GluK2 mutations that impair the LBD (GluK2-T659V, GluK2A487L; Fig. 3) abolished kainate $(25 \mu \mathrm{M})$ evoked $\left[\mathrm{Ca}^{2+}\right]_{\mathrm{i}}$ responses compared to GluK2-WT (Fig. 8). Co-expression of GluK5-WT with GluK2-T659V or GluK2-A487L does not rescue receptor function and only very few transfected 


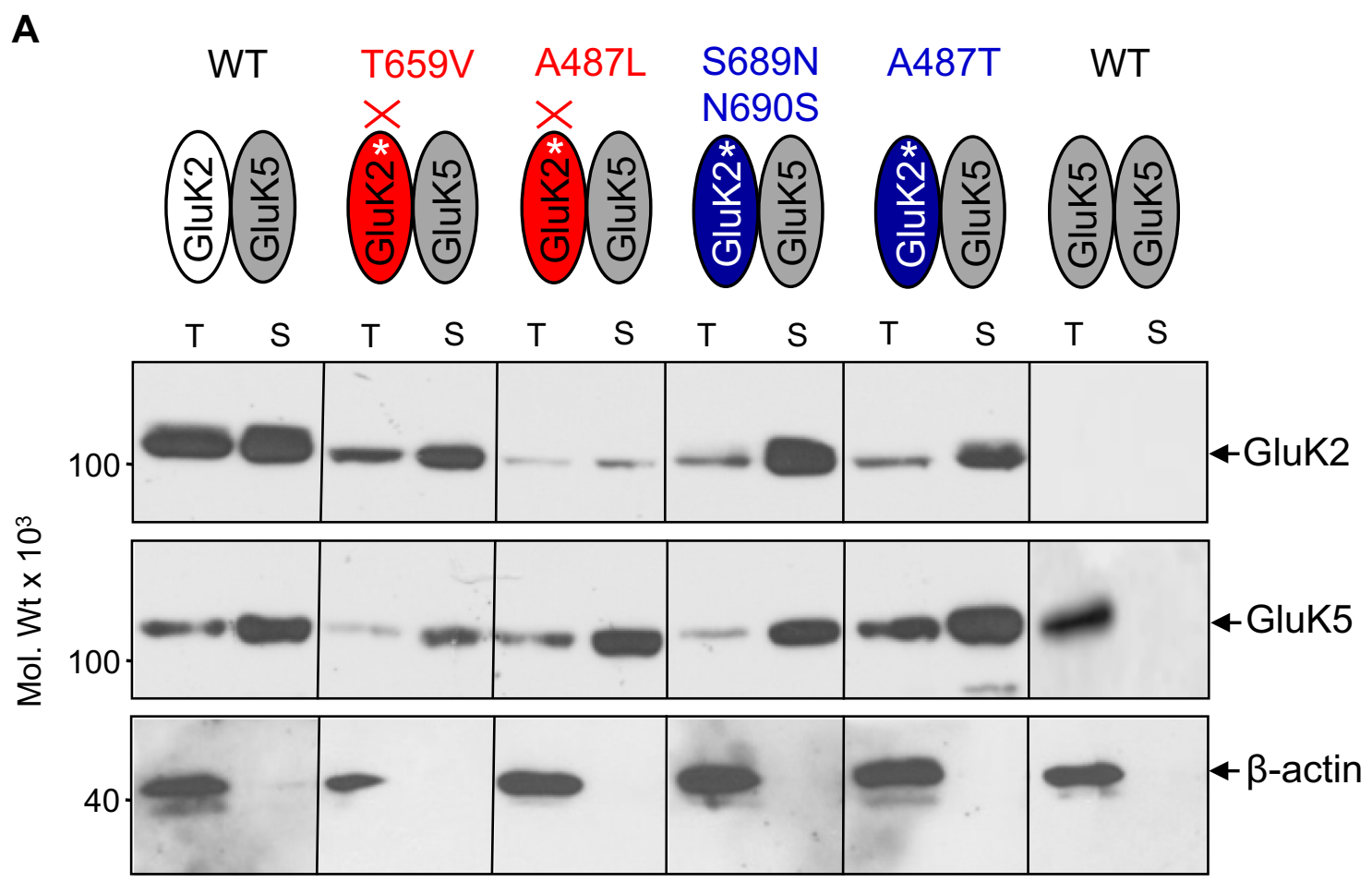

B

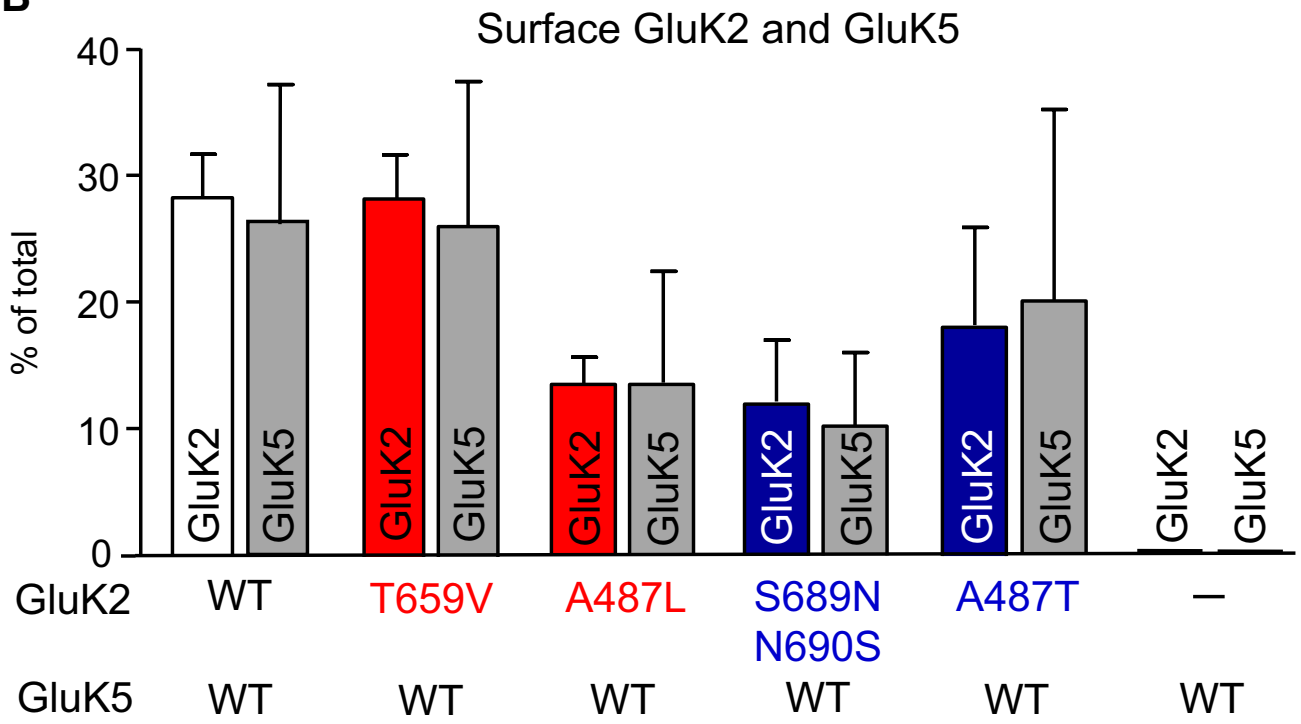

Fig. 7 GluK5 co-expression restores the cell surface trafficking of GluK2 with $\mathrm{Thr} / \mathrm{Val}$ or Ala/Leu mutations. a Wild type (WT) and mutant GluK2 subunits (GluK2-T659V, GluK2-A487L, GluK2S689N/N690S, GluK2-A487T) were co-expressed with the GluK5 WT subunit in transiently transfected HEK293 cells. Following surface biotinylation, labelled proteins (S) were isolated using streptavidin coated beads and analysed using immunoblotting using antiGluK2/3 and anti-GluK5 antibodies. T is $10 \%$ of total protein. The

cells responded to kainate (Fig. 8), despite the presence of functional LBDs in GluK5 and improved cell surface expression of GluK2/GluK5 heteromers (Fig. 7). This $\beta$-actin immunostaining confirmed that biotinylation only labelled cell surface exposed proteins. b Comparison of surface (biotinylated) GluK2 and GluK5 subunits (\% of total) indicates no significant differences between the various LBD mutant and WT subunits (Data are mean \pm SEM, $n=3,{ }^{*} p<0.05$, Student's $t$ test). As expected, the intracellularly retained GluK5-WT [11] was not detectable on the cell surface when it was expressed without GluK2

suggests that agonist binding to GluK5 alone is not sufficient for the opening of the ion channel and functional GluK2 LBDs are required for the activation of GluK2/ 

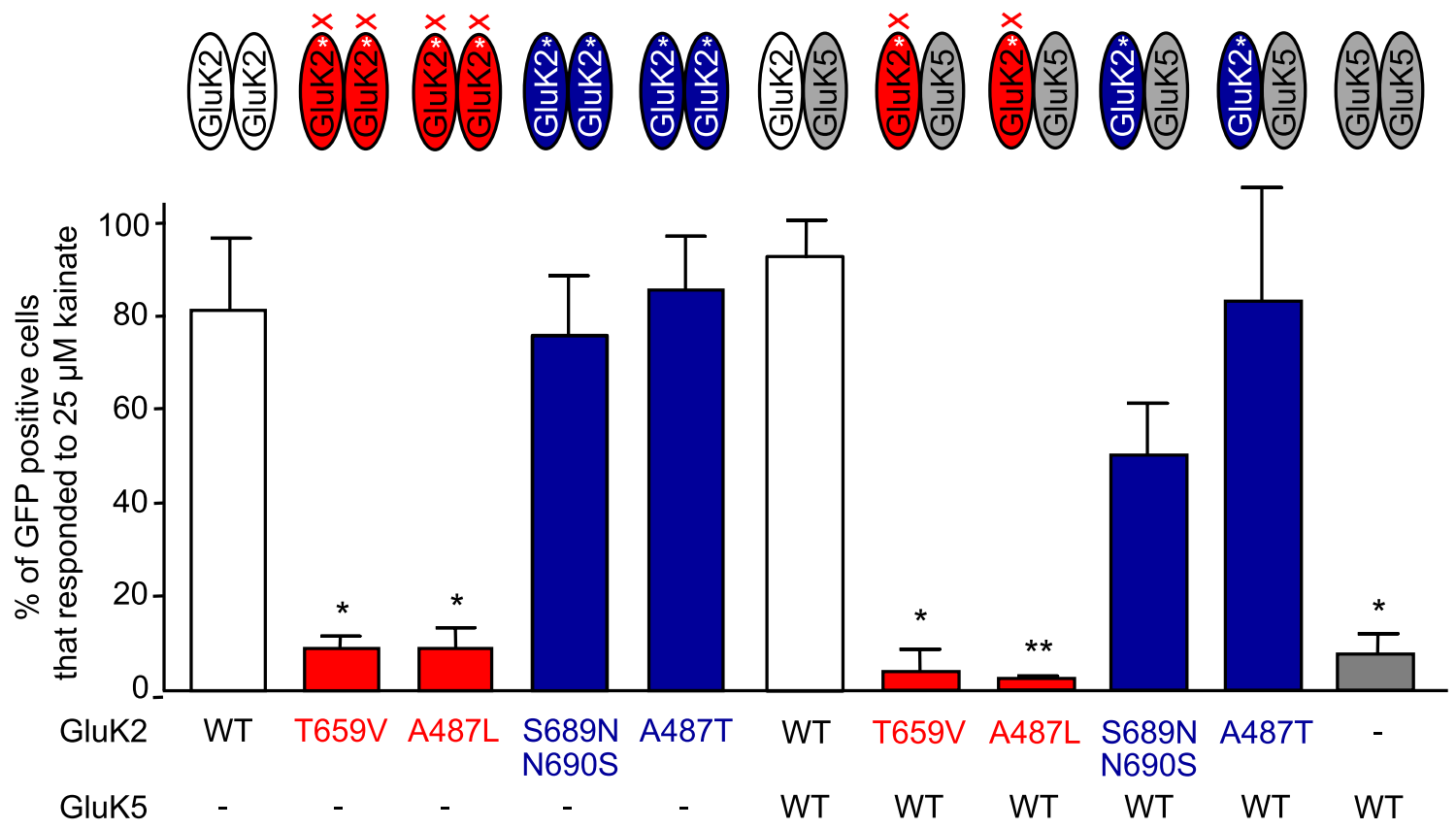

Fig. $8 \mathrm{Thr} / \mathrm{Val}$ and Ala/Leu mutations of GluK2 abolish kainateinduced responses of both homomeric GluK2 and heteromeric GluK2/GluK5 receptors. Wild type (WT) or mutant (GluK2-T659V, GluK2-A487L, GluK2-S689N/N690S, GluK2-A487T) GluK2 was expressed as homomer or heteromer with WT GluK5 in HEK293 cells as indicated. Following incubation with fura-2-AM, $25 \mu \mathrm{M}$ kainate-induced increase in $\left[\mathrm{Ca}^{2+}\right]_{\mathrm{i}}$ was measured in GFP positive transfected cells. GluK2 mutants with impaired LBD (GluK2-T659V and

GluK5 heteromers. Due to the fast desensitisation rate of GluK3 that cannot be blocked by the addition of ConA [47], we did not include GluK3 in $\left[\mathrm{Ca}^{2+}\right]_{\mathrm{i}}$ imaging studies.

\section{Discussion}

We found that mutations of conserved residues in the LBDs (GluK2-A487, GluK1-T675, GluK2-T659, GluK3T661) hindered both kainate and MG binding to all low affinity subunits of KARs. In contrast, exchanging nonconserved T/A amino acid residues between GluK1 and GluK2 subunits (GluK1-T503A, GluK2-A487T, GluK3T489A) did not alter kainate binding. While reciprocal mutations of the non-conserved N/S residues in GluK1-3 (GluK1-N705S/S706N, GluK2-S689N/N690S, GluK3N691S) enabled agonist binding, the kainate binding activities of mutant subunits shifted from the parent subunit towards that of the subunit the mutation was designed to imitate. In line with previous studies, mutations that impair ligand binding to GluK2 and GluK3 also disrupted the trafficking of homomeric KARs and lead to the intracellular retention of these subunit proteins [17, 46] (Fig. 9). In contrast, exchanging non-conserved
GluK2-A487L; red bars) have significantly fewer cells that respond to kainate with an increase in $\left[\mathrm{Ca}^{2+}\right]_{\mathrm{i}}$ compare to GluK2-WT or subunit conversion mutants (GluK2-S689N/N690S, GluK2-A487T; blue bars). Co-expression of GluK5-WT has not altered the kainateevoked responses of LBD mutant GluK2 subunits. Data are mean \pm SEM $(n=3),{ }^{*} p<0.05, * * * p<0.005$ mutants compared to WT, Student's $t$ test. (Color figure online)

residues in the GluK2 and GluK3 LBDs has no significant effect on their glycosylation and cell surface expression profiles. Co-assembly with the WT high affinity GluK5 subunit can override ER retention of mutant GluK2 with impaired LBD and promotes the cell surface expression of both subunits. However, $\left[\mathrm{Ca}^{2+}\right]_{i}$ imaging indicates that the occupancy of both GluK2 and GluK5 LBDs is required for the full activation of heteromeric KAR channels (Fig. 9).

Previous studies revealed that ligand binding and associated conformational changes are necessary for the biogenesis of KARs and their trafficking from the ER through the Golgi network to the cell surface in both homo- and heteromeric assemblies [14-16, 46, 48]. Our study of conserved and non-conserved residues in the LBDs of GluK1-3 with impaired and maintained ligand binding activities confirmed and extended these studies to other KAR subunits and amino acid residues. While the occupancy of the LBD enhances the cell surface expression of KARs, the opening of the ion channel pore appears to be not necessary [14, 46]. However, restricting the ligand-induced conformational changes reduces the cell surface expression of KARs [15, $18,46]$. The intracellular retention is not due to gross protein misfolding, because LBD mutant KAR subunits are capable of assembly [14, 15] and do not show increased 


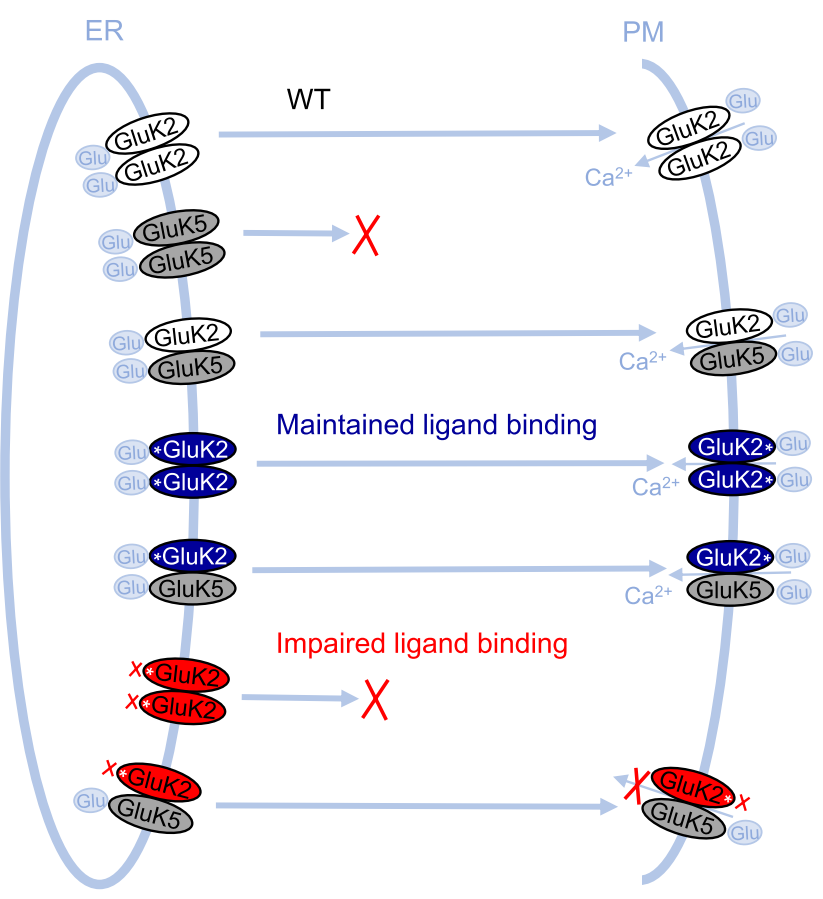

Fig. 9 A schematic illustration of the assembly and trafficking of homomeric and heteromeric KARs with functional and impaired ligand binding sites. While GluK2 subunit proteins with functional LBD are readily expressed on the cell surface ( $P M$ plasma membrane) alone or in combination with GluK5, GluK2 with impaired ligand binding sites are retained in intracellular compartments (ER endoplasmic reticulum). The cell surface expression of GluK5 depends on co-assembly with GluK2. Co-expression with GluK5 restores the surface expression of GluK2 subunits with impaired LBD (red), but these receptors are non-functional despite the presence of active ligand binding sites in GluK5. This suggests that agonist binding to GluK5 is not sufficient to open the ion channel and activation of GluK2 is required for the activation of GluK2/GluK5 heteromeric KARs. (Color figure online)

degradation rate [15]. Our results are consistent with these findings. When expressed individually, GluK2 subunits with impaired LBDs (GluK2-A487L, GluK2-T659V) and GluK5WT are all retained in the ER with very limited or no cell surface trafficking and no detectable change in degradation rates. However, when GluK2-A487L or GluK2-T659V was co-expressed with GluK5-WT, the ER retention domains of GluK5 [11, 12, 49] was shielded in the GluK2/GluK5 heteromer and enabled the surface expression of both subunits. This also suggests that glutamate binding to GluK5 alone is sufficient for the cell surface expression of the GluK2/ GluK5 complex. Indeed, the disruption of glutamate binding to GluK5 leads to a reduction in the plasma membrane expression and intracellular retention of GluK2/GluK5 heteromers $[15,16]$. Collectively these findings suggest a dominant role for the GluK5 LBD in the glutamate mediated cell surface trafficking of the GluK2/GluK5 complex. The
GluK5 subunit may act as a possible modulator of GluK2 trafficking or folding, ensuring that the protein reaches the correct conformation to be trafficked.

GluK2 and GluK5 are both widely expressed in the CNS [50] and they preferentially assemble [42] with 2:2 stoichiometry [7] as pairs of heterodimers [51, 52] to form functional KARs. Unlike GluK2, GluK5 does not form functional homomeric channels even when the ER retention/retrieval motif is removed [15]. Because functional expression of GluK5 requires co-assembly with other KARs subunits, it is difficult to investigate the pharmacological properties of GluK5 in isolation. Newly synthesised KAR antagonists are routinely tested on subunits expressed in HEK293 cells for their ability and selectivity to reduce L-glutamate induced calcium-influx by using a FlexStation [6, 33]. Based on previous studies we anticipated that the co-expression of GluK5-WT with impaired LBD containing GluK2 would provide a cell-based assay for the screening of GluK5 selective ligands. While the presence of the functional LBD in GluK5 and the masking of ER retention motifs in GluK5 by GluK2 LBD mutants enable the cell surface trafficking of GluK5-WT/GluK2T659V and GluK5-WT/GluK2-A487L heteromers, exposure to kainate does not produce changes in $\left[\mathrm{Ca}^{2+}\right]_{\mathrm{i}}$. This suggests that occupancy of GluK5 LBDs in the heteromeric assembly is sufficient for forward trafficking of the subunit assembly, but agonist binding to GluK2 is required for the opening of the KAR channel pore. Furthermore, previous pharmacological studies of GluK1/GluK5 heteromeric complexes demonstrated that GluK1 can gate current without concomitant activation of their partner GluK5 subunits and occupancy of binding sites on individual KAR subunits activates distinct channel conductance and kinetic properties [53]. It is also possible to activate GluK2/GluK5 heteromers through agonist binding to the GluK2 subunit while GluK5 is inhibited by domoate $[36,54]$. Even though the individual subunits can be activated separately, the GluK2 subunit may still need to be bound to a ligand and inducing a prolonged current before the GluK5 can react to bound agonist. Another possible explanation for the lack of activation seen in heteromeric assemblies is that when there is no ligand bound to the GluK2 subunit only the GluK5 subunit is able to react. It is not known if ConA effectively blocks the desensitisation of GluK5, which could mean that the GluK5 subunit is desensitising too quickly to produce a detectable change in $\left[\mathrm{Ca}^{2+}\right]_{\mathrm{i}}$. However, electrophysiological studies suggest that activation of GluK5 subunits by agonist activates the KARs without inducing desensitisation [36, 55]. Another possibility is that the LBD dimer interface in the GluK5WT/GluK2-T659V and GluK5-WT/GluK2-A487L heterodimers is not stable when the GluK5 LBD is closed, and the GluK2 LBD is open, which may promote entry into the 
desensitised state and/or enhance the rate of deactivation. Stability of the dimer interface and of the hinge region, which serves as the pivot point for LBD closure, has been shown to be necessary to block desensitisation and slow deactivation, respectively, of AMPARs [56, 57]. While it is not possible to perform functional assays, it may be possible to use the GluK5-WT/GluK2-T659V and GluK5-WT/ GluK2-A487L heteromers in competition binding assays to screen compounds on GluK5.

The biosynthesis, assembly and cell surface trafficking of KARs are key determinants of neuronal network excitability in the CNS $[1,3]$. This study further highlights the pharmacological chaperone role of glutamate in KAR trafficking and the differential functions of various subunits. Defining the distinct roles of various subunits is essential for the development of selective ligands for the targeted modulation of KARs in the CNS. Intriguingly, epilepsyassociated mutations in the GluN2A NMDAR subunit that caused reduction in agonist potency also showed significantly decreased expression levels and trafficking to the cell surface [58]. Functional and pharmacological analyses of mutant KAR and other iGluR subunits [47, 58-60] would provide interesting insight into the molecular mechanism of associated neurological and psychiatric disorders.

Acknowledgements This work was supported by the UK Medical Research Council (Grant G061509) and the Biotechnology and Biological Sciences Research Council (Grant BB/J015938/1). CLS was a UK Medical Research Council-funded PhD student.

\section{Compliance with Ethical Standards}

Conflict of interest DEJ and EM are Scientific Advisory Board members of Hello Bio (http://www.hellobio.com).

Open Access This article is distributed under the terms of the Creative Commons Attribution 4.0 International License (http://creativeco mmons.org/licenses/by/4.0/), which permits unrestricted use, distribution, and reproduction in any medium, provided you give appropriate credit to the original author(s) and the source, provide a link to the Creative Commons license, and indicate if changes were made.

\section{References}

1. Lerma (2006) Kainate receptor physiology. Curr Opin Pharmacol 6:89-97

2. Molnár E (2018) Glutamate receptors. In: Choi S (ed) Encyclopedia of signaling molecules, 2nd edn. Springer, Berlin, pp 2138-2146

3. Lerma J, Marques JM (2013) Kainate receptors in health and disease. Neuron 80:292-311

4. Valbuena S, Lerma J (2016) Non-canonical signaling, the hidden life of ligand-gated ion channels. Neuron 92:316-329

5. Møllerud S, Frydenvang K, Pickering DS, Kastrup JS (2017) Lessons from crystal structures of kainate receptors. Neuropharmacology 112:16-28
6. Jane DE, Lodge D, Collingridge GL (2009) Kainate receptors: pharmacology, function and therapeutic potential. Neuropharmacology 56:90-113

7. Reiner A, Arant RJ, Isacoff EY (2012) Assembly stochiometry of the GluK2/GluK5 kainate receptor complex. Cell Rep 1:234-240

8. Bernard A, Ferhat L, Dessi F, Charton G, Represa A, Ben-Ari Y, Khrestchatisky M (1999) Q/R editing of the GluR5 and GluR6 kainate receptors in vivo and in vitro: evidence for independent developmental, pathological and cellular regulation. Eur J Neurosci 11:604-616

9. Pahl S, Tapken D, Haering SC, Hollmann M (2014) Trafficking of kainate receptors. Membranes 4:565-595

10. Evans AJ, Gurung S, Henley JM, Nakamura Y, Wilkinson KA (2018) Exciting times: new advances towards understanding the regulation and roles of kainate receptors. Neurochem Res. https ://doi.org/10.1007/s11064-017-2450-2 (Epub ahead of print)

11. Gallyas F, Ball S, Molnar E (2003) Assembly and cell surface expression of KA-2 subunit-containing kainate receptors. J Neurochem 86:1414-1427

12. Ren Z, Riley NJ, Garcia EP, Sanders JM, Swanson GT, Marshall J (2003) Multiple trafficking signals regulate kainate receptor KA2 subunit surface expression. J Neurosci 23:6608-6616

13. Nasu-Nishimura Y, Hurtado D, Braud S, Tang TTT, Isaac JTR, Roche KW (2006) Identification of an endoplasmic reticulumretention motif in an intracellular loop of the kainate receptor subunit KA2. J Neurosci 26:7014-7021

14. Mah SJ, Cornell E, Mitchell NA, Fleck MW (2005) Glutamate receptor trafficking: endoplasmic reticulum quality control involves ligand binding and receptor function. J Neurosci 25:2215-2225

15. Valluru L, Xu J, Zhu Y, Yan S, Contractor A, Swanson GT (2005) Ligand binding is a critical requirement for plasma membrane expression of heteromeric kainate receptors. J Biol Chem 280:6085-6093

16. Fisher JL, Housley PR (2013) Agonist binding to the GluK5 subunit is sufficient for functional surface expression of heteromeric GluK2/GluK5 kainate receptors. Cell Mol Neurobiol 33:1099-1108

17. Fleck M (2006) Glutamate receptors and endoplasmic reticulum quality control: looking beneath the surface. Neuroscientist 12:232-244

18. Priel A, Selak S, Lerma J, Stern-Bach Y (2006) Block of kainate receptor desensitisation uncovers a key trafficking checkpoint. Neuron 52:1037-1046

19. Sander T, Hildmann T, Kretz R, Furst R, Sailer U, Bauer G, Schmitz B, Beck-Mannagetta G, Wienker TF, Janz D (1997) Allelic association of juvenile absence epilepsy with a GluR5 kainate receptor gene (GRK1) polymorphism. Am J Med Genet $74: 416-421$

20. Li JM, Zeng YJ, Peng F, Li L, Yang TH, Hong Z, Lei D, Chen Z, Zhou D (2010) Aberrant glutamate receptor 5 expression in temporal lobe epilepsy lesions. Brain Res 1311:166-174

21. Crépel V, Mulle C (2015) Physiopathology of kainate receptors in epilepsy. Curr Opin Pharmacol 20:83-88

22. Casey JP et al (2012) A novel approach of homozygous haplotype sharing identifies candidate genes in autism spectrum disorder. Hum Genet 131:565-579

23. Aller MI, Pecoraro V, Paternain AV, Canals S, Lerma J (2015) Increased dosage of high-affinity kainate receptor gene grik4 alters synaptic transmission and reproduces autism spectrum disorders features. J Neurosci 35:13619-13628

24. Motazacker MM, Rost BR, Hucho T, Garshasbi M, Kahrizi K, Ullmann R et al (2007) A defect in the ionotropic glutamate receptor 6 gene (GRIK2) is associated with autosomal recessive mental retardation. Am J Hum Genet 81:792-798 
25. Formicola D, Aloia A, Sampaolo S, Farina O, Diodato D, Griffiths LR, Gianfrancesco F, Di Iorio G, Esposito T (2010) Common variants in the regulative regions of GRIA1 and GRIA3 receptor genes are associated with migraine susceptibility. BMC Med Genet 11:103

26. Pickard BS, Malloy MP, Christoforou A, Thomson PA, Evans KL, Morris SW et al (2006) Cytogenetic and genetic evidence supports a role for the kainate-type glutamate receptor gene, GRIK4, in schizophrenia and bipolar disorder. Mol Psychiatry $11: 847-857$

27. Luciano M, Houlihan LM, Harris SE, Gow AJ, Hayward C, Starr JM, Deary IJ (2010) Association of existing and new candidate genes for anxiety, depression and personality traits in older people. Behav Genet 40:518-532

28. Knight HM, Walker R, James R, Porteous DJ, Muir WJ, Blackwood DH, Pickard BS (2012) GRIK4/KA1 protein expression in human brain and correlation with bipolar disorder risk variant status. Am J Med Genet 159B:21-29

29. Falcón-Moya R, Sihra T, Rodríguez-Moreno A (2018) Kainate receptors: role in epilepsy. Front Mol Neurosci 11:217

30. Zhuo M (2017) Ionotropic glutamate receptors contribute to pain transmission and chronic pain. Neuropharmacology 112:228-234

31. Zhou M (2017) Cortical kainate receptors and behavioural anxiety. Mol Brain 10:16

32. Atlason PT, Scholefield CL, Eaves RJ, Mayo-Martin MB, Jane DE, Molnár E (2010) Mapping the ligand binding sites of kainate receptors: molecular determinants of subunit-selective binding of the antagonist $\left[{ }^{3} \mathrm{H}\right] \mathrm{UBP} 310$. Mol Pharmacol 78:1036-1045

33. Larsen AM, Bunch L (2011) Medicinal chemistry of competitive kainate receptor antagonists. ACS Chem Neurosci 2:60-74

34. Kaczor AA, Karczmarzyk Z, Fruzin A, Pihlaja K, Sinkkonen J, Wiinamaki K, Kronbach C, Unverferth K, Poso A, Matosiuk D (2014) Structural studies, homology modelling and molecular docking of novel non-competitive antagonists of GluK1/GluK2 receptors. Bioorg Med Chem 22:787-795

35. Larsen AP, Fièvre S, Frydenvang K, Francotte P, Pirotte B, Kastrup JS, Mulle C (2017) Identification and structure-function study of positive allosteric modulators of kainate receptors. Mol Pharmacol 91:576-585

36. Fisher MT, Fisher JL (2014) Contributions of different kainate receptor subunits to the properties of recombinant homomeric and heteromeric receptors. Neuroscience 278:70-80

37. Solly K, Klein R, Rudd M, Holloway MK, Johnson EN, Henze D, Finley MFA (2015) High-throughput screen of GluK1 receptor indentifies selective inhibitors with a variety of kinetic profiles using fluorescence and electrophysiology assays. J Biomol Screen 20:708-719

38. Perrais D, Pinheiro PS, Jane DE, Mulle C (2009) Antagonism of recombinant and native GluK3-containing kainate receptors. Neuropharmacology 56:131-140

39. Mayer ML (2005) Crystal structures of the GluR5 and GluR6 ligand binding cores: molecular mechanisms underlying kainate receptor selectivity. Neuron 45:539-552

40. Ball SM, Atlason PT, Shitu-Balogun OO, Molnár E (2010) Assembly and intracellular distribution of kainate receptors is determined by RNA editing and subunit composition. J Neurochem 114:1805-1818

41. Molnár E (2016) Investigation of neurotransmitter receptors in brain slices using cell surface biotinylation. In: Luján R, Ciruela F (eds) Receptor and ion channel detection in the brain. Neuromethods, vol 110. Humana Press, New York, pp 39-48
42. Wenthold RJ, Trumpy VA, Zhu WS, Petralia RS (1994) Biochemical and assembly properties of GluR6 and KA2, two members of the kainate receptor family, determined with subunit specific antibodies. J Biol Chem 269:1332-1339

43. Molnar E, Varadi A, McIlhinney RAJ, Ashcroft SJH (1995) Identification of functional ionotropic glutamate receptor proteins in pancreatic $\beta$-cells and in islets of langerhans. FEBS Lett 371:253-257

44. Gladding CM, Collett VJ, Jia Z, Bashir ZI, Collingridge GL, Molnár E (2009) Tyrosine dephosphorylation regulates AMPAR internalisation in mGluR-LTD. Mol Cell Neurosci 40:267-279

45. Mott DD, Rojas A, Fisher JL, Dingledine RJ, Benveniste M (2010) Subunit-specific desensitization of heteromeric kainate receptors. J Physiol 588(4):683-700

46. Gill MB, Vivithanaporn P, Swanson GT (2009) Glutamate binding and conformational flexibility of ligand-binding domains are critical early determinants of efficient kainate receptor biogenesis. J Biol Chem 284:14503-14512

47. Matute C (2011) Therapeutic potential of kainate receptors. CNS Neurosci Ther 17:661-669

48. Fleck MW, Cornell E, Mah SJ (2003) Amino-acid residues involved in glutamate receptor 6 kainate receptor gating and desensitization. J Neurosci 23:1219-1227

49. Hayes DM, Braud S, Hurtado DE, McCallum J, Standley S, Isaac JT, Roche KW (2003) Trafficking and surface expression of the glutamate receptor subunit, KA2. Biochem Biophys Res Commun 310:8-13

50. Petralia RS, Wang YX, Wenthold RJ (1994) Histological and ultrastructural localization of the kainate receptor subunits, KA2 and GluR6/7, in the rat nervous system using selective antipeptide antibodies. J Comp Neurol 349:85-110

51. Kumar J, Schuck P, Mayer ML (2011) Structure and assembly mechanism for heteromeric kainate receptors. Neuron 71:319-331

52. Paramo T, Brown PMG, Musgaard M, Bowie D, Biggin PC (2017) Functional validation of heteromeric kainate receptor models. Biophys J 113:2173-2177

53. Swanson GT, Green T, Sakai R, Contractor A, Che W, Kamiya H, Heinemann SF (2002) Differential activation of individual subunits in heteromeric kainate receptors. Neuron 34:589-598

54. Fisher JL (2014) The neurotoxin domoate causes long-lasting inhibition of the kainate receptors GluK5 subunit. Neuropharmacology 85:9-17

55. Fisher JL, Mott DD (2011) Distinct functional roles of subunits within the heteromeric kainate receptor. J Neurosci 31:17113-17122

56. Sun Y, Olson R, Horning M, Armstrong N, Mayer M, Gouaux E (2002) Mechanism of glutamate receptor desensitisation. Nature 417:245-253

57. Jin R, Clark S, Weeks AM, Dudman JT, Gouaux E, Partin KM (2005) Mechanism of positive allosteric modulators acting on AMPA receptors. J Neurosci 25:9027-9036

58. Addis L, Virdee JK, Vidler LR, Collier DA, Pal DK, Ursu D (2017) Epilepsy-associated GRIN2A mutations reduce NMDA receptor trafficking and agonist potency-molecular profiling and functional rescue. Sci Rep 7:66

59. Yuan H, Low C-M, Moody OA, Jenkins A, Traynelis SF (2015) Ionotropic GABA and glutamate receptor mutations and human neurologic diseases. Mol Pharmacol 88:203-217

60. Xu XX, Luo JH (2018) Mutations of $N$-methyl-D-aspartate receptor subunits in epilepsy. Neurosci Bull 34:549-565 